\title{
A Ciência Política Brasileira Diante do Novo Regime Fiscal: Para uma Agenda de Pesquisas sobre Democracia e Austeridade
}

\author{
Francisco Tavares ${ }^{1}$ \\ Gustavo Silva ${ }^{2}$ \\ ${ }^{1}$ Professor adjunto na Faculdade de Ciências Sociais da Universidade Federal de Goiás (UFG) e docente dos \\ programas de pós-graduação em Ciência Política e em Direitos Humanos da UFG. Goiânia, GO, Brasil. \\ E-mail: francktavares@hotmail.com, https://orcid.org/0000-0002-3905-8141 \\ ${ }^{2}$ Mestrando em Ciência Política pela Universidade Federal de Goiás (UFG) e bacharel em direito pela UFG. \\ Goiânia, GO, Brasil. \\ E-mail: gustavosabinoalcantara@gmail.com, https:/ orcid.org/0000-0001-8713-7330
}

\section{INTRODUÇÃO}

Em dezembro de 2016, o Congresso Nacional brasileiro promulgou a Emenda Constitucional 95 (Brasil, 2016). A norma redesenhou em contornos radicalmente distintos as bases do direito financeiro vigente no país. Foi instituído um Novo Regime Fiscal que, em síntese, impôs um congelamento real vintenário ${ }^{1}$ dos dispêndios primários (excluídos, portanto, os gastos com o serviço da dívida pública) da União, sob mínimas exceções ${ }^{2}$. A vedação ao aumento real de gastos não se limitou em elementos sazonalmente oscilantes, a exemplo de expansão populacional, transformações demográficas, crescimento econômico ou aumento da arrecadação fiscal ${ }^{3}$.

O descumprimento do teto orçamentário acarretará sanções institucionais ${ }^{4}$, assim entendidas como medidas coercitivas que não recaem sobre os agentes políticos ou técnicos, mas sobre o poder público enquanto tal. Há, na Emenda Constitucional em questão, uma gradação sancionatória que se inicia em proibição de aumentos ou reajustes de vencimentos de servidores públicos e pode alcançar a vedação à realização de concursos para admissão de novos quadros na administração pública. 
A coibição do aumento de gastos estatais traduz uma medida do governo brasileiro que, somada a alterações nas legislações trabalhista ${ }^{5}$ e previdenciária", encerra "uma forma de deflação voluntária [...] para restaurar a competitividade, o que é (supostamente) melhor alcançado por meio de cortes no orçamento, nas dívidas e nos défices do governo" (Blyth, 2015: p. 2) ${ }^{7}$. Trata-se, portanto, de uma variante brasileira do disseminado e global fenômeno da adoção de uma fiscalidade austera como reação a um contexto de crise econômica. Coerentemente, a justificativa da referida Emenda Constitucional indica a pretensão de se promover desenvolvimento econômico por meio da consolidação fiscal, sob a premissa teórica de que essa política "restabelecerá a confiança dos agentes" e "reduzirá o risco país", o que a predicaria como um "instrumento essencial para recolocar a economia brasileira em trajetória de crescimento" (Meirelles e Oliveira, 2016).

A Emenda Constitucional 95/2016 ostenta, portanto, uma compreensão da economia política adstrita à noção de "austeridade expansionista" baseada em redução de despesas, antes de aumento dos tributos. Essa concepção pressupõe que, sob um ambiente de ostensivo sacrifício governamental a indicar aos agentes de mercado o compromisso com o serviço da dívida pública, reduz-se o risco dos respectivos títulos. Consequentemente, há condições favoráveis para o decréscimo dos juros, com impacto positivo sobre a oferta de crédito e sobre a confiança na estabilidade macroeconômica do país. As decisões dos empreendedores quanto à realização de novos investimentos tendem, assim, a ser mais prováveis, o que permite crescimento econômico e um ambiente de prosperidade (Alesina, Favero e Giavazzi, 2015). A confirmação empírica desse argumento é objeto de intensa controvérsia e abundam estudos cujas aferições contradizem a expectativa de que a contração orçamentária possa influenciar o investimento privado ou a confiança nos negócios (Guajardo, Leigh e Pescatori, 2011; Haffert e Mehrtens, 2013). Para a perspectiva teórica keynesiana, as medidas restritivas associadas ao que atualmente se define como austeridade tendem a não apenas se frustrarem quanto ao objetivo de expansão econômica, mas aprofundam o ciclo recessivo, uma vez que o próprio subtraem liquidez da economia precisamente quando esta seria mais necessária (Rosa, 2016).

O contexto histórico em que o Novo Regime Fiscal foi aprovado compreendeu um cenário de recessão econômica e instabilidade política. A medida fora proposta nos primeiros meses de um governo que assu- 
miu após a cassação, pelo parlamento, do mandato da presidente eleita em 2014 e, já no início de 2017, passou a produzir efeitos no direito financeiro brasileiro. Nesse ambiente, ocorreram processos como a mobilização de estratos abastados, com ressonância em camadas mais amplas da população ${ }^{8}$, contra a majoração de tributos no país. Sob um cenário de dificuldade fiscal, entre o aumento de receitas por meio da modificação de um sistema tributário marcado por inusuais renúncias às exações sobre o capital $^{9}$ (Gobetti e Orair, 2016) e a redução das despesas, o Governo favoreceu esta última opção. Foi uma escolha coerente, a um só tempo, com os aparentes anseios dos setores sociais que se mobilizaram pela cassação da antecessora do presidente que encaminhou o Novo Regime Fiscal ao Legislativo e com a linha do pensamento econômico para a qual os tributos não devem ser utilizados como instrumentos redistributivos.

O fluxo de acontecimentos que deságua no congelamento de gastos públicos primários compreende, sob o ângulo do contexto sócio-histórico em que se desdobra, uma interseção entre três dos assim denominados "ingredientes" do quadro político brasileiro no período, tal como identificados por Fabiano Santos e José Szwako, nomeadamente a crise fiscal, a crise política e a recessão aguda (Santos e Szwako, 2016) ${ }^{10}$.

O Novo Regime Fiscal, ainda que não resista como norma jurídica de direito financeiro constitucionalizado ao longo dos anos, tende a produzir consequências para além do tempo em que estiver formalmente em vigor, em face do modo como incide sobre instituições, políticas públicas e interesses políticos, conforme se discutirá adiante, na segunda seção deste artigo. O que se constata, porém, é que a medida - ou, quando menos, seus fundamentos associados à austeridade fiscal - não deve deixar a cena institucional brasileira em curto prazo. O presidente eleito em 2018, Jair Bolsonaro, nomeou como ministro da Fazenda o economista Paulo Guedes, que não apenas defendeu a Emenda Constitucional 95/2016 ao longo da campanha eleitoral como, uma vez investido em sua função, manteve na Secretaria do Tesouro Nacional um dos seus idealizadores, o economista Mansueto de Almeida Júnior.

O teto vintenário de gastos públicos primários imposto à União não esgota as suas implicações sobre o âmbito diretamente econômico. $\mathrm{O}$ escopo deste artigo, com efeito, cinge-se à dimensão política do Novo Regime Fiscal brasileiro. A pesquisa aqui apresentada pretendeu, sob 
o prisma teórico, responder à indagação acerca dos possíveis temas, linhas e perguntas que se apresentam para a Ciência Política brasileira diante do cenário aberto pela promulgação da Emenda Constitucional 95/2016. Sugere-se uma agenda de estudos e investigações referenciada nas transformações de natureza política associadas à sua promulgação, sob a premissa de que, em medida ainda superior aos aspectos imediatamente associados ao mercado ou à contabilidade pública, a norma acarreta consequências sobre a dinâmica decisória do Estado brasileiro ${ }^{11}$.

Para desenvolver o argumento de que política e fiscalidade se imbricam mutuamente, a segunda seção, dedica-se à justificação teórica da centralidade do âmbito fiscal para a dinâmica de conflitos e tomadas de decisões no Estado moderno, seguida de uma definição da categoria "regime fiscal" cujo significado revela um paralelismo com a noção de regime político. Na seção seguinte, sobre um solo teórico já pavimentado quanto ao caráter centralmente fiscal e tributário da moderna politicidade, semeia-se uma abordagem, ancorada em recentes elaborações no âmbito da teoria democrática e da economia política, segundo a qual os regimes de austeridade em voga mundialmente, em especial a partir da crise iniciada em 2008, não se compatibilizam plenamente com a política democrática, ainda que entendida em termos minimalistas ${ }^{12}$. Na seção final, já com vistas a se formular uma resposta para a indagação teórica que move este artigo, indicam-se elementos preliminares para uma agenda de pesquisas centrada na tensa relação entre a democracia e o Novo Regime Fiscal brasileiro.

\section{A IMBRICAÇÃO ENTRE POLÍTICA E FISCALIDADE NA DINÂMICA DO ESTADO MODERNO}

Ao se debruçar sobre a formação do Estado, Norbert Elias constata que ao weberiano monopólio dos meios para o exercício da violência legítima acopla-se o monopólio da tributação. Esse atributo indiscernível do Estado moderno, conforme o autor o percebe a partir do exemplo francês, teria surgido de modo paulatino e em meio a uma miríade de conflitos sociais. Sob arbitramento real (as antigas aide féodales, de ordem contratual e episódica), as disputas ocorridas entre a nobreza decadente, a burguesia ascendente e populares despossuídos deram forma, em meio a um processo mantido ao longo de séculos e acometido por inúmeras reviravoltas, ao monopólio estatal da tributação - ao qual corresponde uma máquina pública e uma lógica de dispêndios 
que se revelam indissociáveis do Estado, tal como concebido atualmente. Em síntese, ao se referir à "forma de organização social que chamamos de Estado", Norbert Elias constata que o "monopólio da tributação, juntamente com o monopólio da força física, formam a espinha dorsal da organização" (Elias, 2011:177).

A partir dessa percepção, seria de se supor que a Ciência Política estivesse especialmente dedicada aos conflitos sociais referentes às finanças públicas. Esta, todavia, não é a realidade do campo, ao menos no Brasil. Um recente levantamento bibliométrico concentrado na comparação entre o fazer científico-político do Brasil com o de outros países chegou a notar a presença destacada de temas sociológico-políticos em solo brasileiro. De outro lado, porém, ao identificar as 15 palavras mais frequentes em títulos e resumos de publicações em periódicos, não constatou nenhuma ocorrência expressa ou obliquamente relacionada ao âmbito das finanças públicas (Codato, 2018). É válido supor que a especialização dos campos da Ciência Política e da Economia no Brasil, a par de permitir incontáveis avanços teóricos e metodológicos, deixou um vazio temático no que tange ao tratamento da relação entre política, sociedade e finanças públicas. Como adiante se detalha, a Ciência Política referenciada em conflitos de ordem tributária e orçamentária é venturosa e encontra, na história do século $X X$, promissores momentos, em geral associados ao campo interdisciplinar da sociologia fiscal.

No início do século $X^{13}$, o sociólogo austríaco Rudolph Goldscheid propôs que a tributação e o orçamento seriam a chave explicativa dos conflitos sociais e das transformações do Estado, desde os contextos absolutistas, até a sua forma alcançada no capitalismo avançado ${ }^{14}$. Até mesmo as lutas de ordem religiosa ou espiritual seriam explicadas, para essa linha de entendimento, segundo pressões e disputas tributárias ou associadas às finanças públicas (Goldscheid, 1994). Lançavam-se assim as bases de um campo científico que posteriormente seria denominado como sociologia fiscal, para o qual a política e a cultura só podem ser devidamente compreendidas em sua relação com tributos e dispêndios estatais. Estes, igualmente, exorbitariam a esfera da economia, das limitações jurídicas ao poder de tributar ou das técnicas de gestão, de vez que definiriam em grande medida as sociedades em que se manifestam. 
J. Schumpeter, um economista e cientista social que compartilhava a origem austríaca com Goldscheid e dele extraiu uma leitura que entende as finanças públicas como variáveis centrais para a compreensão das sociedades, é o criador da expressão "sociologia fiscal". A história das finanças públicas seria, em sua obra, não apenas um acessório, mas parte essencial da História Geral. O raciocínio segue e chega à notória máxima de que "o espírito de um povo, seu nível cultural, sua estrutura social e os feitos que a sua política pode preparar - tudo isso e mais é escrito em sua história fiscal, despida de todo fraseado" (Schumpeter, 1991:101) ${ }^{15}$.

É insólita, com efeito, a centralidade conferida pelo cânone da Ciência Política de influência anglófona à contribuição schumpeteriana à teoria democrática contemporânea ${ }^{16}$ ao menos quando cotejada com a integralidade de sua vasta obra, em meio à qual há uma teoria do Estado própria e singular que permanece insuficientemente tratada por essa área do conhecimento.

Por um lado, o texto que mais frequentemente impulsiona debates nesse campo acadêmico, "Capitalismo, Socialismo e Democracia", apresenta-se como uma obra cuja pergunta teorética condutora não corresponde à formulação de um entendimento sobre o Estado moderno e, ainda menos, sobre um modelo específico de democracia. De fato, ainda no prefácio redigido em 1942 para o livro que se tornaria clássico, Schumpeter é explícito ao dispor que produzira um texto sobre o problema do socialismo e, apenas incidentalmente, fora conduzido a uma digressão mais extensa sobre a democracia (Schumpeter, 1961).

Por outro, o prócer da concepção minimalista de democracia que ainda movimenta o debate teorético-político no Ocidente produziu uma teoria instigante e genuína sobre o Estado moderno e suas idiossincrasias. Ainda em 1918, em sua fase europeia e 24 anos antes da publicação do livro que o notabilizaria entre politólogos, o economista de formação austríaca publicou The Crisis of the Tax State (Schumpeter, 1991). Ali, desenhou-se uma robusta definição da forma político-estatal como específica à modernidade e da sua quintessencial constituição a partir da relação política e jurídica atinente à tributação.

Ancorado na história prussiana, Schumpeter edificou uma narrativa segundo a qual a relação tributária se constituiu, na transição entre o feudalismo e o Estado moderno, como o elemento fundamental apto 
à delimitação política, jurídica e econômica do espaço público. A separação entre o domínio econômico e a soberania política - discrímen da moderna sociedade - se realiza e se explica em termos fiscais, de tal ordem que predicar o Estado moderno como "Tax State" seria quase um pleonasmo, haja vista a central importância dos tributos e do orçamento na conformação da diferenciação sobre a qual se fundam as relações sociais no capitalismo. Sobre tais bases, Schumpeter propôs a sociologia fiscal, disciplina orientada a entender não apenas a economia, mas a cultura e a política, das sociedades com foco no Estado, sua natureza, suas formas e seu destino. Estes elementos, por sua vez, seriam compreendidos a partir dos tributos e dos orçamentos públicos. Os estudos sociofiscais expressariam a virtude de se ouvir o "trovão da história", clamando pelo potencial explicativo do tema em todas as esferas da sociedade (Schumpeter, 1991).

O chamado de Goldscheid e Schumpeter encerrou antes o momento terminal de uma apreensão interdisciplinar dedicada à economia e à sociedade, do que o marco de uma nova e emergente disciplina ${ }^{17}$. A autonomização e especialização das humanidades ao longo do século XX - cujos méritos epistêmicos são amplamente reconhecidos - acabou por relegar temas como os aspectos culturais e políticos das finanças públicas a um hiato entre Economia, Sociologia e Ciência Política, o que impediu que o campo científico proposto pelos autores florescesse como esperado (Martin, Mehrotra e Prasad, 2009). A inexistência de uma disciplina como a Sociologia Fiscal e a carência de pesquisas interdisciplinares orientadas à tributação e aos gastos públicos não implicaram, todavia, o esvanecimento do tema nas bases constitutivas das teorias do Estado que ancoraram o debate a respeito da democracia e do poder político nas últimas décadas. A seguir, explica-se esta afirmação.

É válida, por um lado, a constatação de que a teoria democrática contemporânea encerra, a partir da segunda metade do século $X X$, um consenso procedimentalista (Santos e Avritzer, 2003) que segue desde o minimalismo democrático inscrito na obra de Schumpeter ainda nos anos 1940, até as formulações "contra-hegemônicas" como, por exemplo, aquelas que saúdam o valor normativo das experiências participativas conduzidas nos processos de transição democrática ocorrentes no Sul Global (Avritzer, 2009, 2010) ou as que incorporam concepções 
agonísticas segundo as quais o ativismo e o protesto se inserem no leque de ações entendidas como válidas participações político-democráticas (Young, 2001).

Por outro, é lícito detectar que na obra dos mesmos cientistas sociais que se dedicaram à discussão do procedimentalismo democrático há preocupações vinculadas à teoria do Estado, em relação às quais a dimensão fiscal recebe invariável centralidade. O debate tributário e orçamentário como anteparo da temática procedimental é uma presença indiscriminadamente notada, seja nas elaborações de cunho tradicional, seja nas formulações críticas. Os exemplos abaixo, nem longinquamente exaustivos ou sistematicamente representativos da vastidão que contempla os estudos teórico-políticos do século XX, são suficientes para indicarem a plausibilidade dessa constatação.

Na corrente principal da teoria democrática contemporânea, reitera-se que o respectivo prócer e cânone, J. Schumpeter, adota uma teoria do Estado para a qual as finanças públicas se definem como o mais relevante aspecto da política, da economia e até mesmo da cultura no capitalismo. Soma-se a essa referência outro formulador de primeira ordem no procedimentalismo entendido como hegemônico ou tradicional, Anthony Downs. Como se sabe, este nome associado à teoria da public choice sintetizou a sua definição de governo democrático como "aquele escolhido periodicamente por meio de eleições populares nas quais dois ou mais partidos competem pelo voto de todos os adultos" (Downs, 1999:56). Poucos anos após o aparecimento de sua célebre Uma teoria econômica da democracia, o autor complementou o argumento e conferiu-lhe tons fiscais. Movido pelo objetivo de entender por que governos costumam gastar menos do que se espera em regimes democráticos, Downs asseverou que "cada eleição nacional pode ser considerada como uma disputa entre dois orçamentos governamentais prospectivos" $(1960: 546)^{18}$.

O relativo consenso procedimentalista da teoria democrática erigida ao longo do século XX não se separa, nem mesmo analiticamente, ao menos nas correntes de maior influência e menor ânimo crítico ou normativo, de uma premissa teórica segundo a qual o elemento substantivo inscrito na arrecadação tributária e no orçamento estatal estabelece os termos e os limites da disputa democrática. Esta não é uma constatação trivial, uma vez que, acaso o Estado se veja em uma crise fiscal que comprometa sua capacidade de arrecadar ou gastar 
recursos, a sua política democrática será, por via reflexiva, igualmente prejudicada, senão inviabilizada ${ }^{19}$. Há, portanto, uma base substantiva sobre a qual repousa até a mais formal das teorias democráticas ligadas às correntes majoritárias da Ciência Política. Esta base se constitui das finanças públicas, tanto no sentido da arrecadação de tributos, como no da definição dos gastos orçamentários do Estado.

Também as variantes críticas e as de fôlego preponderantemente normativo da teoria democrática contemporânea estão edificadas sobre colunas teóricas que entendem a relação jurídica de direito tributário e os dispêndios estatais como inextricavelmente atados à política no Estado moderno. Um exemplo reside no procedimentalismo habermasiano. A democracia deliberativa - cujas bases remontam a Faticidade e validade, publicado em 1992 - foi a resposta final ao problema da crise de legitimação no capitalismo tardio, perquirido por Habermas em 1973, ainda na fase preparatória à sua obra magna, Teoria da ação comunicativa, publicada em 1981. O défice de legitimação habermasiano se explica como um problema de ordem fiscal, ao tempo em que reside precisamente em uma falha estatal - sob um contexto de sobrecarga orçamentária decorrente de custos como transporte, ciência, previdência, lazer etc. - na tarefa de "elevar o nível necessário dos impostos, subtraindo lucros e rendas, e usar os impostos disponíveis racionalmente de modo que os distúrbios das crises do crescimento possam ser evitados" (Habermas, 2002:82) ${ }^{20}$.

Igualmente atenta ao âmbito fiscal é a contribuição de fôlego histórico apresentada por Charles Tilly aos estudos sobre a democracia. Para o autor, a expansão do Estado e da sua atuação demanda um incremento na extração, gênero cuja principal manifestação específica na modernidade é a tributação. Esta elevação, por sua vez, exige barganhas e negociações com os cidadãos que, no longo prazo, tendem a promover a democratização (Tilly, 2007). Assim, a história das democracias pode ser contada, em certa medida, como a história da autorização cidadã para a elevação dos tributos ou das obrigações de semelhante natureza em favor do Estado.

Como se vê, o procedimentalismo nas teorias da democracia caminha paralelamente às noções de história e de teoria do Estado para as quais os processos decisórios - desde eleições até a participação institucional - assentam-se sobre uma base substantiva fiscal. Esta premissa explica o modo como o conceito de "regime fiscal", cerne deste artigo, 
se revela homólogo à ideia de "regime político". A decomposição analítica daquela categoria em três componentes, tal como desenhada por Pierson (2001) e incorporada por Haffert e Mertens (2013), ajuda a justificar esse ponto.

A tese, produzida sob a influência do neoinstitucionalismo histórico, postula que um regime fiscal compreende arranjos que dispõem sobre os conflitos acerca da tributação e dos gastos públicos, configurando três elementos: interesses políticos, instituições e políticas. Essas três dimensões produzem efeitos combinados recíprocos, em função da implementação ou da transformação dos regimes fiscais. Por exemplo, um regime fiscal definido pela austeridade carrega a necessidade da criação de instituições fiscalizadoras dos dispêndios estatais, conduz a uma predileção por políticas sociais focais em detrimento das universais e (re)alinha os interesses políticos, de modo que, à míngua de gastos estatais vultosos, o eleitorado busque arcar de forma particular com suas demandas (saúde, educação, transporte etc.) e tenda a escolher partidos que ofertem menor sacrifício tributário. Haffert e Mertens (2013) constatam, adicionalmente, que apenas sob contextos de profunda crise e de intensa coordenação de esforços políticos é que se pode alterar um regime fiscal - que, desse modo, se revela difícil de ser erigido e igualmente pouco suscetível quanto a modificações.

Em síntese, se a política no Estado moderno se explica em ampla medida a partir dos conflitos fiscais e se um regime fiscal dispõe sobre uma combinação raramente modificável das dimensões institucional, gerencial-administrativa e político-competitiva desses conflitos, então fica claro que uma reforma constitucional que redefine as bases orçamentárias do Estado - como se deu no Brasil a partir de 2017 - compreende, outrossim, uma profunda alteração de ordem política, apta a ensejar consequências decisivas sobre as relações de poder na sociedade. É seguro, com esteio nas proposições teóricas aqui expostas, supor que a mudança de um regime fiscal traduz um significativo impacto sobre o processo político. Com efeito, uma vasta gama de pesquisadores tem se dedicado às consequências que os regimes fiscais austeros produzem sobre a democracia, tal como estudada e compreendida na segunda metade do século XX. Essa possível relação entre austeridade e perecimento dos regimes democráticos é o tema da próxima seção. 


\section{A "ERA DA AUSTERIDADE" E AS AMEAÇAS À DEMOCRACIA}

Como sugere uma leitura reversa da relação tilliana entre expansão estatal e democratização, regimes de austeridade podem importar consequências deletérias sobre as democracias ${ }^{21} \mathrm{e}$ condicionar regimes políticos. Uma influente referência sobre o assunto é W. Streeck (2011, 2014, 2016). A partir de uma narrativa histórica que segue dos arranjos político-econômicos consolidados após a Segunda Guerra Mundial à contemporânea crise econômica global, pontua-se que o Estado Fiscal de Schumpeter e Goldscheid cede terreno, atualmente, ao Estado Dívida e ao Estado Consolidação, no contexto do qual a frágil e contraditória amarração entre democracia e capitalismo parece encontrar o seu limite. Segundo esse argumento, após a Segunda Guerra Mundial estabeleceu-se, pelo menos na Europa ocidental e nos Estados Unidos, o capitalismo democrático, assim entendido como uma política econômica regida por dois princípios ou regimes de alocação de recursos conflitantes. Um deles opera de acordo com a produtividade marginal e o outro é baseado nas necessidades ou direitos sociais decorrentes das escolhas coletivas materializadas nas políticas democráticas (Streeck, 2011). Os mercados, por um lado, precisam da estabilidade política propiciada pela democracia, de modo que as relações econômicas capitalistas encontrem aceitação junto às coletividades. De outro lado, precisamente as medidas de intervenção que fazem do capitalismo socialmente aceitável incorrem contra o equilíbrio econômico esperado pelo mercado. Diante dessa inevitabilidade das crises (políticas ou econômicas), o que o Estado pode fazer é esgueirar-se entre ambas e, assim, ganhar algum tempo (Streeck, 2014, 2016).

Para obter recursos e remeter os problemas ao futuro em meio às sucessivas crises econômicas e tensões políticas, os Estados democráticos do norte global, após a Segunda Guerra Mundial, lançaram mão de três consecutivas soluções que, sem resolver a tensão constitutiva do vínculo entre política democrática e economia capitalista, concederam efêmero alívio aos regimes políticos democráticos: inflação (emissão de moeda sem o esperado impacto no aumento da produção futura), dívida pública (emissão de títulos da dívida estatal) e dívida privada (desregulação do mercado de capitais). A crise encontrou cada uma dessas medidas em algum momento, e o contexto atual, ao menos para essa perspectiva teórica, experimentaria um limite inédito e - até aqui - intransponível na acomodação entre economia capitalista e política democrática (Streeck, 2011). 
O Estado, nesse contexto, sofre uma profunda transformação em sua lógica política. Uma constituency composta da construção sociocoletiva ("os mercados") tende a se sobrepor, paulatina mas ininterruptamente, à abstração subjetiva associada à legitimidade estatal ("o povo"). Como notam Schäfer e Streeck, mercados operariam em escala internacional (ao passo em que povos ficam limitados às nações), teriam em sua base investidores que agiriam como credores (derrotando os cidadãos, que atuam como eleitores), contariam com os direitos de crédito e resgate sobre os títulos da dívida do Estado (e assim sobrepujariam pessoas que têm direitos de cidadania), seriam continuamente ouvidos em audiências (diferentemente das pessoas, que se fazem escutadas nos momentos eleitorais), influenciariam a política ao incidirem sobre o nível dos juros (que repõem, assim, o papel outrora atribuído à opinião pública) exigiriam confiança (antes de lealdade) e avaliariam o Estado em razão de sua capacidade de pagar a dívida (em vez de priorizar o serviço público). Um a um, os elementos constitutivos do pacto democrático triunfante no norte global após a Segunda Guerra Mundial são substituídos por peças que retiram a soberania popular, em favor de uma prevalência dos mercados (Schäfer e Streeck, 2013).

O processo de reversão do Estado Social em favor de políticas de austeridade tem início no norte global ainda nos anos 1970 e paulatinamente chega ao sul global. No caso brasileiro, a cultura do ajuste e da consolidação fiscal do Estado fora, ao menos nas décadas de 1980 e 1990, minimamente mitigada pelo processo de afirmação de direitos ocorrente durante a transição democrática e os primeiros anos da Constituição de 1988. Esse cenário, de avanço do neoliberalismo em meio à efervescente organização da sociedade que superava um anterior regime de exceção, fora definido por Evelina Dagnino como "confluência perversa" (Dagnino, 2004). No mundo contemporâneo - em especial após os colapsos fiscais decorrentes do regaste do setor financeiro após a crise de 2008 - e no Brasil em que a Nova República já apresenta sinais de desgaste ou mesmo de colapso (Safatle, 2017), o Estado austero parece aprofundar-se e, com isso, os riscos sobre a política democrática.

Ainda antes da crise econômica global em curso, o cientista político C. Crouch descreveu o momento histórico atual sob a perspectiva da inoperância dos mecanismos democráticos de decisão pública. $\mathrm{O}$ argumento é que as eleições, os direitos fundamentais, as instituições de accountability e as práticas políticas do paradigma anterior à elevação dos mercados sobre os povos podem se manter, mas já não é ali que as 
efetivas decisões estatais são proferidas (Crouch, 2004). A liberalização da economia, associada à imposição de limites fiscais rígidos aos Estados, em especial no que concerne aos seus gastos, inviabilizou a tal ponto a tomada de decisões coletivas sobre os rumos dos governos, que não estaríamos mais vivendo em democracias, mas em pós-democracias. Todos os elementos dos regimes democráticos estão formalmente presentes (eleições, constituições, imprensa livre etc.), mas é extirpada a possibilidade de a população decidir, por meio de seus governantes eleitos, quais gastos, em quais áreas e em que montantes devem ser feitos, o que esvazia, inobstante o sentido ou extensão, qualquer ideia de governo do ou para o demos. Por isso mesmo, a vida pública, em especial a aclamação eleitoral, se reduz, segundo esse entendimento, a um espetáculo midiático e deixa de ser um meio de se alcançar valores e interesses coletivos (Crouch, 2004).

As medidas de austeridade, com efeito, podem encerrar incontáveis consequências sobre o regime político de um Estado. A depender de sua configuração, podem provocar desde o esvaziamento da democracia com a impossibilidade de se decidir coletivamente sobre os gastos que um governo pode fazer, passando pela desmobilização política de seus cidadãos e indo até a influência que se exerce na formação da subjetividade.

No plano da participação política, por exemplo, Schäffer e Streeck identificam uma relação entre o aumento do endividamento dos países da Organização para a Cooperação e Desenvolvimento Econômico (OCDE), a aplicação de medidas de austeridade na tentativa de contornar o problema e a queda de participação nas eleições (Schäfer e Streeck, 2013). Assim, à tese de fôlego macro-histórico da pós-democracia no Estado Consolidação, soma-se um dado empírico de natureza mais concreta: há uma queda de turn out eleitoral no contexto das políticas de austeridade na Europa, e essa queda é mais pronunciada em meio a pessoas pobres, migrantes e jovens, o que indica que, precisamente para quem o Estado não possui recursos que logrem satisfazer as pretensões eleitoralmente escolhidas, a democracia começa a se tornar um jogo desinteressante (Schäfer e Streeck, 2013).

Diante desse cenário de decrescente e seletiva queda na participação eleitoral em países ricos, Claus Offe (2013) revisita a tese de Schattschneider (para quem os menos favorecidos deixam de participar dos processos eleitorais menos por razões de exclusão do direito ao 
voto ou por medidas coercitivas, mas por não identificarem as eleições como meios de melhoria das suas vidas) e constata que, antes de constrangimentos institucionais ou jurídicos à participação das camadas sociais menos privilegiadas (como voto facultativo, eleições em dias laborais ou regras não amigáveis para cadastramento de eleitores), a principal variável explicativa do fenômeno reside no lado da oferta. Sob as pressões fiscais dos dias atuais, governantes tendem a não contemplar as demandas da população mais pobre e menos instruída que, por sua vez, tende a não comparecer às eleições e, assim, passa a não ser considerada nos programas partidários, em um ciclo vicioso que conformaria o quadro de pós-democracia (termo igualmente adotado por Offe) sob o qual os regimes do Norte Global encontrar-se-iam (Offe, 2013). Offe conclui, já com ânimo normativo, que

novos procedimentos podem não ser suficientes para aumentarem e ampliarem a participação dos cidadãos, a menos que o lado da oferta de políticas públicas e de 'espaço de possibilidade' [(...]) seja protegido contra crescentes restrições (Offe, 2013:216).

Sob o ângulo da participação política não eleitoral, há quem postule que o quadro de políticas de austeridade, conectado à redução das possibilidades de efetividade dos fóruns democráticos e ao aumento das desigualdades sociais, defina-se como a principal explicação para os inúmeros ciclos de confronto político ocorrentes no mundo contemporâneo, não apenas no norte global, mas, igualmente, no Oriente Médio, no norte da África e na América Latina (Barker et. al. 2013). Se a democracia sob o arranjo político-econômico pautado por regulação de ordem keynesiana com promoção de direitos sociais sob inspiração beveridgiana (em alusão ao relatório governamental apresentado por Willian Beverdige, na Inglaterra, em 1942, em que reformas sociais eram recomendadas) fora capaz de estabilizar, em grande medida, em termos eleitorais os conflitos sociais, é válido supor, em um contexto de severa restrição orçamentária acompanhado por redução de gastos públicos, que outras maneiras de vocalização das demandas políticas passem a ter lugar, o que pode contribuir para explicar a eclosão de uma "onda global de protestos" (Fominaya, 2014). A incapacidade dos Estados de atenderem às preferências expressadas em processos eleitorais contribui para explicar como, a partir de 2008, dá-se um paradoxal - mas não contraditório - aumento tanto dos repertórios associados à política confrontacional transgressiva, como da apatia eleitoral. 
Donatella della Porta (2015) identifica esse contexto pela ideia de "crise de responsabilidade". Trata-se de algo como a "crise de legitimidade" outrora perquirida por Habermas, mas agora manifestada no plano dos outputs da ação estatal, antes dos inputs de votos e tributos. Nesse quadro, cai a confiança nas instituições democráticas e impera a tendência tanto para a rebelião como para a passividade. Segundo essa concepção, a crise é resultado do suporte estatal aos interesses de grandes corporações e atores de mercado, em prejuízo de direitos sociais, políticos e cívicos, além de associar-se ao aumento da vigilância e à repressão da população em geral.

Essa ideia de "crise de responsabilidade" é especialmente pertinente para a compreensão do momento político vivido sob o primado da austeridade, porque reúne em um só termo múltiplos elementos presentes na literatura sobre o assunto, tais como: i) a transição entre a crise de legitimidade habermasiana e a crise fiscal dos dias atuais (Streeck, 2014); ii) o contexto de "pós-democracia" atravessado pelo governo das corporações em detrimento dos povos (Crouch, 2004) e; iii) a relevância de se atentar para os problemas na oferta de políticas, mais do que nos processos de vocalização e decisão sobre as demandas, para se entender os limites à participação política eleitoral e a conjunção (paradoxal) entre aumento da apatia e surgimento de ciclos de confronto político na contemporaneidade (Offe, 2013; Barker et. al., 2013; Della Porta, 2015).

A filosofia política crítica contemporânea extrai conclusões ainda mais radicais desse quadro histórico. A substituição do "povo" pelos "mercados" como unidades de responsividade política é interpretada por Wendy Brown (2015) como apenas um aspecto de um giro civilizacional iniciado ao final da década de 1970 e aprofundado nos últimos dois lustros. O entendimento é que, sob um mundo neoliberal, todas as esferas da convivência humana são reduzidas aos critérios, parâmetros e valores da economia (não necessariamente do dinheiro, mas sempre da lógica própria ao capital). Nesse quadro em que o povo cede terreno ao mercado, o sujeito do liberalismo clássico dá lugar à firma individual sob a égide do capital humano e o Estado, mesmo quando intervém na economia ou provê direitos sociais, o faz orientado por ideais associados à promoção dos negócios e ao crescimento econômico. Por exemplo, pessoas "investem" na educação das crianças, com vistas à "rentabilidade" da obtenção de vagas em universidades prestigiosas e empregos de sucesso no futuro. Do mesmo modo, governos "investem" na absorção de imigrantes para obter, com a diversidade 
cultural, ambientes favoráveis à criação de ideias que se associem à maior competitividade nos mercados globais. Ou seja, nem mesmo valores como felicidade das crianças ou solidariedade com refugiados comparecem ao público desacoplados de um fundamento mercantil. A ideia de governo do ou para o povo, então, desaparece não apenas em razão da perda do elemento popular mas, adicionalmente, como fruto da substituição da noção de governo pela gerencialista e mercadológica prática de "governança" (Brown, 2015).

Essa gama de interpretações teóricas sobre o momento atual das democracias capitalistas tem como denominador comum a percepção de um momento histórico marcado pela crescente inoperância de um arranjo social fincado no seguinte tripé: i) direitos fundamentais, a garantirem níveis de integridade, liberdade e conforto material satisfatórios; ii) crescente prosperidade econômica, a permitir a materialização desses direitos (Holmes e Sunstein, 1999); e iii) vigência da democracia política a garantir que as pessoas influenciem e tomem parte nas decisões coletivas relevantes. Em meio ao primado quase absoluto do Homo oeconomicus (Brown, 2015), a cena política experimenta alterações significativas, como as seguintes: a) redução das eleições a um espetáculo incapaz de incidir sobre o modo como governantes atuarão, tendo em vista a indisponibilidade de orçamentos públicos para atendimento das demandas manifestadas pelo eleitorado; b) queda de turn out eleitoral ou aumento de votos nulos e brancos, diante de um esperado (e, quanto à Europa, medido e confirmado) desinteresse popular em sufragar candidatos que, malgrado suas intenções ou plataformas políticas, encontrarão limites tributários e orçamentários que os impossibilitarão de atuar com significativa margem discricionária; e c) explosão de formas de participação política confrontacionais, tendencialmente capazes de abrir a cena histórica para novos desenhos político-democráticos, distintos do arranjo atinente ao Estado Social e às democracias partidárias de massa prevalecentes na Europa e nos EUA ao longo da segunda metade do século XX.

Esse contexto tem sido abundantemente estudado, seja empírica ou teoricamente, no norte global. Há, contudo, pouca produção científico-política voltada à compreensão da "Era da Austeridade" na América Latina ${ }^{22}$, e em especial no Brasil. Essa omissão merece ser revista, quando menos em razão de a Emenda Constitucional 95/2016 tratar-se de um caso de austeridade especialmente intenso, em razão de três atributos tão inéditos como pronunciados em matéria de restrição 
orçamentária: i) a política de austeridade fora disposta na Constituição da República, alcançando uma rigidez normativa sem precedentes em outras nações; ii) o prazo de duração do teto real de gastos primários (20 anos) não encontra similar em outras experiências; e iii) a combinação de sanções institucionais nas hipóteses de não observância do teto com a inocorrência de atenuações para a restrição fiscal com base em variáveis como crescimento econômico ou populacional conferiram à medida um caráter de peculiar abrangência e rigidez.

Diante desse cenário, é possível predicar o Brasil como um "caso extremo", segundo a terminologia lançada por B. Flyvbjerg (2006) em seus estudos sobre epistemologia das ciências sociais. Trata-se de contexto social e cientificamente venturoso, uma vez que permite a identificação de mecanismos associados a um determinado fenômeno social de manifestação geral e menos intensa, em um grau de ostensividade especialmente apto a revelar-lhe os atributos e impactos, gerando vantagens para a compreensão em relação aos casos típicos. Nesses, fenômenos como a austeridade fiscal, por exemplo, não aparecem de modo tão agudo e nítido para a mais clara compreensão dos respectivos impactos ${ }^{23}$. Essa peculiar característica da Emenda Constitucional 95/2016 conduz o Brasil à condição de solo fértil para vicejarem pesquisas orientadas à compreensão não apenas econômica, mas política das medidas de austeridade. Assim, sob a premissa de que um regime fiscal exerce significativo impacto nos arranjos políticos de um determinado país, propõe-se, na seção seguinte, um preliminar rol de questões que podem conformar uma agenda de pesquisas voltada ao entendimento da relação entre política democrática e fiscalidade austera, a partir do extremo caso brasileiro.

\section{EXEMPLOS DE TEMAS E PROBLEMAS PARA UMA AGENDA DE PESQUISAS}

As seções anteriores procuraram justificar dois argumentos teóricos: i) a política fiscal é mais do que um elemento incidental do Estado na contemporaneidade, mas define e condiciona todo o seu funcionamento; e ii) ao menos no norte global, há consistente fundamentação teórica e suficientes dados empíricos a indicarem os regimes fiscais de austeridade como potencialmente nocivos à política democrática.

Essas premissas, uma vez cotejadas com as peculiaridades do caso brasileiro, descortinam o horizonte para que se efetivem promissores estudos orientados à compreensão dos riscos e impactos impostos 
à política e à sociedade no Brasil, por ocasião da promulgação da Emenda Constitucional 95/2016. Antes, porém, de se enunciar um rol de perguntas promissoras para uma agenda dedicada à compreensão da reconfiguração do Estado e da política no Brasil após a vigência do Novo Regime Fiscal, é necessário identificar ao menos duas ${ }^{24}$ peculiaridades quanto ao caso brasileiro, que justificam a pesquisa sobre a relação entre política e austeridade no país, uma vez que os achados concentrados nos países da OCDE aqui não se aplicam necessariamente. Opta-se por não ancorar a agenda de pesquisas proposta sobre um diagnóstico maximalista das peculiaridades brasileiras, uma vez que outros aspectos, usualmente entendidos como exclusivos do sul global ou do Brasil, podem ser vistos, ainda que incidentalmente, em países da Europa ou nos EUA ${ }^{25}$.

i) A intensidade sui generis da restrição fiscal brasileira: como já se afirmou anteriormente, ao se explicar a natureza de caso extremo do Novo Regime Fiscal brasileiro, trata-se de medida revestida de abrangência material, rigidez normativa e alcance temporal sem precedentes em outras experiências. Por exemplo, em um Working Paper elaborado para o Fundo Monetário Internacional, Göstan Ljungman (2008) produziu dados sobre as experiências de tetos orçamentários implementadas na Finlândia, na Holanda e na Suécia. O trabalho constata, quanto à extensão, que o maior lapso temporal implementado - Finlândia e Holanda - compreendeu um quadriênio, ao passo que a Suécia, em um regime de definição anual do teto com base nos dois exercícios anteriores, implementou um sistema com alcance de três anos. O texto alerta para os riscos de um teto orçamentário definido em um governo extravasar-se para o mandato seguinte, pois o governante eleito sob prioridades distintas poderia considerar as restrições anteriormente impostas como inaceitáveis. $\mathrm{O}$ referido estudo, também no que diz respeito à rigidez normativa, nota que "em nenhum dos três casos estudados o teto foi determinado em legislação e em nenhum dos casos foram predeterminadas sanções em caso de descumprimento"26 (Ljungman, 2008:48).

Nem mesmo a experiência dos Estados Unidos atinente à Lei de Controle Orçamentário (Budget Control Act) é tão rígida como a brasileira. Ali, se impôs um sequestro fixo de valores a cada ano, com vistas à progressiva redução dos gastos estatais. A medida, entretanto, foi implementada por lei ordinária, tem duração equivalente à metade da EC 95/2016 e poupa despesas como seguridade social, benefícios de veteranos, créditos tributários restituíveis, seguro-desemprego, 
programas de saúde como Medicaid e Programa de Assistência Temporária para Famílias Necessitadas. De fato, um estudo elaborado pela consultoria do Congresso dos EUA antevê que, tendo em vista as exceções ao teto orçamentário vigentes naquele país, até 2021 (data em que a medida expira) os gastos federais terão subido de uma média anual de $19,47 \%$ do PIB para $21,3 \%$, o que se explica não apenas pelo aumento no pagamento de juros da dívida mas, igualmente, de despesas obrigatórias (Driessen e Labonte, 2015).

ii) A reduzida eficácia dos direitos fundamentais no Brasil: a Constituição brasileira de 1988 compreende um vasto rol de direitos sociais, devidamente associados a sofisticados mecanismos fiscais voltados à respectiva implementação. Sabe-se, contudo, que as garantias normativas em questão não alteraram a realidade significativamente, conforme sugerem, por exemplo, as sucessivas emendas constitucionais atinentes à Desvinculação de Receitas da União - medida voltada à desafetação de recursos assinalados à assistência e à saúde - em benefício de despesas fiscais, como o adimplemento da dívida pública. Trata-se, assim, de um país que implementa políticas de austeridade, com necessário impacto sobre os dispêndios associados aos direitos sociais que, em países da América Latina, são significativamente inferiores, como porção do PIB, aos efetivados no norte global (FMI, 2017). Ressai desse atributo uma perplexidade que, por si só, enseja estudos aprofundados. Há, de um lado, sólidos argumentos em favor da ideia de que a constitucionalização no país se define como "simbólica", de tal ordem que "o texto constitucional é uma referência distante dos agentes estatais e cidadãos, cuja práxis desenvolve-se frequentemente à margem do modelo textual da constituição" (Neves, 1996:323). Igualmente, é possível sustentar que as peças orçamentárias "historicamente [...] têm convivido com esvaziamentos fáticos de disposições literais das leis que definem a sua validade e legitimidade jurídica" (Pinto, 2014:71). Por outro lado, tem-se uma situação em que a Constituição é emendada precisamente para que os orçamentos sejam reduzidos, sob o efeito esperado de que menos gastos públicos exorbitantes ao serviço da dívida, a exemplo dos dispêndios sociais, sejam efetivados. É possível que estudos políticos de ordem fiscal levantem dados empíricos e permitam a construção de categorias teóricas que superem tanto as afirmações categóricas sobre um suposto caráter apenas formal dos direitos constitucionais no Brasil, como as percepções para as quais a Constituição de 1988 teria erigido, por si só, um Estado de bem-estar social. 
Estabelecidas essas duas peculiaridades, encontra-se pavimentada a via para a formulação de perguntas de pesquisa que, sem nenhuma aspiração de exaustividade, podem fundamentar o caráter promissor e relevante de uma agenda dedicada aos aspectos políticos do Novo Regime Fiscal brasileiro.

\section{Ciclo Político de Negócios, Ciclo Político de Austeridade e Austeridade Jurídica Inata}

Stephen Kaplan (2013), ancorado em uma pesquisa que utilizou técnicas oscilantes desde testes estatísticos até entrevistas em profundidade com diversos chefes de Estado e inúmeras autoridades fazendárias, identificou os processos e mecanismos que explicam fenômenos como a adoção, por alguns governos orientados ao espectro de centro-esquerda, de políticas econômicas austeras na América Latina.

Kaplan decidiu avaliar a ocorrência dos "ciclos políticos de negócios" (Nordhaus, 1975) como explicações para as políticas de austeridade no subcontinente. Nessas situações, aumentam-se os gastos públicos logo antes dos processos eleitorais, de modo a se promover a elevação dos níveis de crescimento e emprego, com ulterior ocorrência de inflação ou recessão - e redução de gastos - no início dos mandatos.

A descoberta de Kaplan (2013) reside na constatação de que o processo acima descrito não é a regra na América Latina, em razão de duas específicas peculiaridades verificadas em alguns países do subcontinente, como Argentina e Brasil, nomeadamente a "troca" da dívida pública de credores concentrados para títulos espraiados por incontáveis portadores e a traumática memória de períodos marcados por hiperinflação.

Quanto à primeira questão, Kaplan (2013) detecta que, invertendo o que ensinam as lições convencionais de lógica da ação coletiva, credores descoordenados e múltiplos tendem a influenciar os Estados da América Latina e suas decisões em favor de políticas austeras com maior eficácia e probabilidade do que credores coordenados e em pequeno número. Este entendimento decorre da percepção de que, no tempo em que os países deviam preponderantemente para organismos como o Fundo Monetário Internacional (FMI) ou para poucos e concentrados bancos, as negociações em favor do descumprimento das condicionalidades que pressupunham consolidação fiscal e a obtenção de novos créditos diante da insolvência em relação a dívidas pretéritas 
eram relativamente comuns. De outro modo, a profusão de títulos sob anônimos proprietários que costumam associá-los a diversificadas carteiras leva a uma pressão para que os Estados indiquem rápida e inequivocamente sua solvência, sob pena de terem de elevar os prêmios em juros para títulos que circulam freneticamente, ao ritmo das voláteis oscilações de mercado.

No que tange ao segundo elemento que pode modificar os "ciclos políticos de austeridade", Kaplan (2013) percebe que, em países marcados por histórico inflacionário, o eleitorado pode aceitar e expressar preferência por medidas de contração, desde que indiquem sua eficácia para a coibição de uma escalada nos preços. Assim, diferentemente do que ocorre no norte global, identifica-se um apelo popular associado ao refreamento de um problema ali não experimentado, qual seja, a descontrolada elevação dos níveis de inflação.

Quando esses dois elementos ocorrem concomitantemente, os governos tendem a impor, antes das eleições, medidas de austeridade que reduzem a inflação e o crescimento econômico e, assim, esperam ser premiados pelos eleitores. Trata-se da frequente hipótese em que o "ciclo político de negócios" cede terreno ao "ciclo político de austeridade" (Kaplan, 2013).

O marco explicativo formulado por Stephen Kaplan é, possivelmente, o mais atual e robustamente lastreado em dados empíricos para a compreensão da relação entre a política eleitoral e as práticas de contração fiscal ocorrentes ao longo do século XXI na América Latina. Ocorre, porém, que o caso brasileiro da Emenda Constitucional 95/2016 parece exceder à sua capacidade explicativa.

O fato é que um governante que assumiu o ofício por meio distinto das eleições (o impedimento de sua antecessora, de quem fora vice-presidente) insculpiu no texto constitucional um regime de austeridade com duração de 20 anos. Vê-se, assim, que o ciclo político-eleitoral parece tornar-se irrelevante no caso brasileiro, em que a austeridade se revela inata, imune ao escrutínio por meio do sufrágio e às oscilações cíclicas decorrentes do modo como o eleitorado percebe fenômenos econômicos como a inflação, o crescimento e os níveis de emprego. Em suma, trata-se de uma austeridade jurídica inata, alheia à política democrática. Entender os processos sociais que conduziram a tal desdobramento e as suas consequências para a política e a democracia é 
um desafio que a agenda de pesquisas aqui sugerida pode encampar. É possível, desde já, formular a hipótese de que a tese crouchiana da "pós-democracia" manifesta-se, no Brasil, de um modo peculiar e mais profundo, ao tempo em que o próprio texto constitucional subtrai do eleitorado a possibilidade de influenciar sobre a decisão, petrificada de modo vintenário, atinente ao congelamento de quase todos os gastos públicos, em favor da priorização absoluta do adimplemento do serviço da dívida pública.

\section{A Emenda Constitucional 95/2016 e a Qualidade da Democracia Brasileira}

Em 2016, Leonardo Morlino e Mario Quaranta publicaram um artigo em que, ancorados em seus trabalhos prévios associados à ideia de qualidade da democracia, avaliaram os efeitos da crise econômica europeia sobre os elementos que compõem essa categoria, nomeadamente: primado do direito, accountability eleitoral, accountability interinstitucional, participação, competição, liberdade, igualdade e responsividade. Concluiu-se que os contextos de turbulência na economia se relacionam com queda na qualidade da democracia, o que se percebe por meio de uma deterioração do primado do direito, um aumento da sensibilidade das pessoas em relação à ação governamental, com decréscimo da responsividade e um alheamento em relação à política institucional, com opção por práticas como protesto (Morlino e Quaranta, 2016).

Morlino e Quaranta ressalvaram dois aspectos que deveriam ser ulteriormente considerados em outras pesquisas referentes ao tema. Primeiramente, reconheceram-se os limites decorrentes da circunstância de coleta de evidências restringir-se à União Europeia, para se sugerir a ampliação dos levantamentos em direção a uma base empírica mais ampla. Em segundo lugar, pontuou-se que uma avaliação mais cuidadosa das políticas sociais e econômicas implementadas pelos governos em contextos de crises econômicas poderia ensejar a respectiva identificação como variáveis intervenientes sobre os resultados encontrados em relação à qualidade dos regimes democráticos (Morlino e Quaranta, 2016).

O caso da Emenda Constitucional 95/2016 permite um enfrentamento desses dois aspectos. Primeiramente, por se tratar de um contexto de crise econômica em país não europeu, as variáveis testadas por Morlino e Quaranta poderão ser compreendidas em um ambiente que amplie os horizontes geográficos da pesquisa sobre a relação entre crise econô- 
mica e qualidade da democracia. O mais relevante, todavia, reside na possibilidade de se perscrutar o efeito da escolha de uma política fiscal jamais implementada em outras nações (teto orçamentário vintenário em norma constitucional, com previsão de sanções institucionais), na condição de variável interveniente a influenciar a qualidade da democracia, a partir de uma crise econômica e política entendida como variável independente a desencadear a política em questão.

\section{Impactos do teto orçamentário Vintenário sobre a Democracia Fiscal}

Imagine-se uma República que fosse revestida de toda sorte de mecanismos de accountability vertical, horizontal e social; normas de transparência que forjassem dados e análises compreensíveis sobre a atuação da administração pública; fóruns participativos definidos por altíssima qualidade deliberativa, em que as decisões obedecessem tanto quanto possível à força não coerciva do melhor argumento e à possibilidade de influência nos respectivos debates por todos os potencialmente afetados; processos eleitorais inclusivos e capazes de permitir o mais informado esclarecimento dos eleitores, a mais ampla garantia do direito de voto e a mais efetiva possibilidade de substituição dos grupos ou partidos no governo. Suponha-se, igualmente, que $100 \%$ do orçamento desse país estivesse comprometido com obrigações pactuadas em anos anteriores, por pessoas e representantes que, possivelmente, já nem mesmo estariam vivos. Sob a perspectiva teórica delineada na segunda seção deste artigo, a nação em questão, inobstante os atributos associados aos respectivos procedimentos, dificilmente seria considerada como democrática. Há, a propósito dessa relação entre disponibilidade orçamentária e democratização política, um conceito econômico-político, devidamente composto por elementos que permitem a geração de um indicador, denominado "democracia fiscal". Formulado por Eugene Steurle (2016) para a realidade dos EUA e com sugestões de adaptações apresentadas por W. Streeck e D. Mertens (2010) para o âmbito alemão, o conceito dispõe, a rigor, sobre a porção das receitas públicas que remanesce após o dispêndio de todos os gastos mandatórios, insuscetíveis de deliberação em âmbito parlamentar ou em espaço democrático equivalente.

Uma aplicação do índice de "democracia fiscal" ao Brasil, de modo a se medir o seu comportamento ao longo da vigência da Emenda Constitucional 95/2016, sugere resultados promissores. Quando as despesas são congeladas, o volume real de recursos públicos subme- 
tido ao debate em âmbito parlamentar tende a se esvair. Tal circunstância, ao longo de 20 anos, acompanhada de fatores como crescimento populacional e ampliação da atividade econômica privada a demandar uma projeção no setor público - quando menos, por força dos acréscimos inevitáveis em órgãos de fiscalização, tribunais e uma mínima infraestrutura de iniciativa estatal - aponta para a hipótese de que os níveis de democracia fiscal no Brasil devem cair significativamente nos próximos anos. A tarefa de adequar o índice de Steuerle à realidade do Brasil e iniciar uma medição anual desde já, orientada por análises que procurem explicar o impacto da EC 95/2016 sobre os resultados alcançados, presta-se a uma melhor compreensão da relação entre política democrática e finanças públicas no país, além de oferecer referências e parâmetros para casos análogos em outros países.

Ademais, é igualmente possível que conflitos políticos e sociais apontem para uma reversão, em algum momento, tanto da Emenda Constitucional 95/2016 como de outras medidas de austeridade, a exemplo da reforma previdenciária defendida pelo governo cujo mandato se iniciou em 2019. Essa relação entre conflitos sociais, rigidez orçamentária e margem fiscal (tanto para a garantia de eficácia aos direitos constitucionais, como para conversão das demandas expressas em processos eleitorais, participativos ou por meio da opinião pública em ações de governo e normas positivas) é um tema vasto, a permitir uma longeva sequência de levantamentos e interpretações que indiquem os mecanismos e processos associados às transformações atinentes às práticas sociais e aos desenhos institucionais referentes ao liame entre conflito político-social e decisões fiscais no Brasil.

\section{Participação política e Regime Fiscal}

Como já exposto, a queda de turn out eleitoral na Zona do Euro pode ser explicada em função de uma malaise concorrente a uma percepção de ineficácia das eleições para colimação das preferências esposadas pelas pessoas, diante da falta de recursos orçamentários para atendê-las no contexto de crise fiscal experimentado pelos Estados. Acrescentou-se a esse entendimento a abordagem de pesquisadores como C. Barker e D. della Porta, para quem os ciclos de confronto político globalmente observados desde 2008 possuem estreita e direta relação com os cortes de direitos e serviços públicos associados às políticas 
de austeridade. Leituras como essas podem inspirar estudos sobre o Novo Regime Fiscal brasileiro, mas exigem desafiantes adaptações para as peculiaridades do país.

Primeiramente, quanto à questão eleitoral, por se tratar de um país definido pela figura jurídica do voto obrigatório, é necessária alguma cautela antes de se lidar com a variável comparecimento às votações como proxy de reconhecimento da responsividade do regime representativo. É possível, de qualquer modo, antever-se a plausibilidade de algumas hipóteses, a partir de dados e interpretações hoje disponíveis. Por exemplo, já se detectou que houve um aumento da abstenção especialmente pronunciado entre eleitores de partidos identificados com a esquerda política no ano de 2016 (Machado, Marques e Campos, 2016) ${ }^{27}$. Pode-se conjugar esse achado - apenas para a formulação de uma hipótese que terá de ser testada com variáveis próprias e previamente delimitadas - com a linha de raciocínio de André Singer (2012) quanto aos eleitores do Partido dos Trabalhadores em 2006. Naquele ano, subsequente ao rumoroso escândalo de corrupção conhecido como "mensalão", mas agraciado pelo "tripé formado pelo bolsa família, pelo [aumento real do] salário mínimo e pela expansão do crédito" (Singer, 2012:68) o candidato petista obteve um contingente maior de votos junto ao eleitorado de baixa renda.

Acaso essas pistas não se confirmem como promissoras, o foco empírico pode ser deslocado do comportamento para as opiniões, com base, por exemplo, no modo como oscilarão as respostas a perguntas que questionam se o entrevistado está de acordo com a ideia de que "a democracia soluciona os problemas que temos", conforme anualmente indagada pela pesquisa Latinobarómetro.

Uma vez confirmadas empiricamente as premissas de que a austeridade inscrita no Novo Regime Fiscal se correlacionará com absenteísmo (comportamento) ou descrença na democracia como capaz de solucionar problemas (opinião) e de que estes elementos estariam mais frequentes entre eleitores pobres, então a tese europeia do descrédito do sistema eleitoral entre os grupos que mais necessitam de gastos estatais sociais, sob regimes de austeridade, poderá se confirmar no Brasil.

Há, entretanto, um longo itinerário a se percorrer quanto ao levantamento de dados (abstenção eleitoral, votos nulos ou brancos, atitudes e opiniões concernentes à democracia, perfil de classe de quem se 
abstém, situação geral da economia e dos gastos estatais, oscilação no tempo do índice de democracia fiscal) e de consequentes explicações teóricas ou identificações de mecanismos. A vigência do teto orçamentário é, assim, um momento especialmente oportuno para a produção desse tipo de pesquisa.

Em segundo lugar, quanto aos recursos e oportunidades para o protesto político, o cenário brasileiro contemporâneo experimenta, igualmente, peculiaridades. Por exemplo, o recrudescimento do tratamento penal ou coercitivo das práticas contestatórias e a redefinição organizativa e ideológica das organizações de movimento, coalizões de campanha e partidos, são aspectos que devem ser levados em consideração, juntamente com as questões fiscais e econômicas, na compreensão dessas dinâmicas. Como se sabe, os exemplos europeus também lidam com uma "reconfiguração do ativismo social" (Bringel e Pleyers, 2015) por si só ambivalente e repleta em eventos ou processos muito distintos entre si, a exemplo do surgimento de partidos como Podemos (Espanha) e Syriza (Grécia), do fenômeno do Movimento Cinco Estrelas (Itália), seguindo-se por acontecimentos como o Brexit (Grã-Bretanha) ou a eclosão e dispersão do Nuit Debout (França). Esses casos, tão diferentes reciprocamente, não podem ser simplesmente transplantados para o entendimento da realidade específica do Brasil. Assim como no caso do comportamento eleitoral, é preciso olhar para momentos anteriores em que houve ajustes fiscais e relacioná-los com eventos de protesto ou ciclos de confrontos políticos. Apenas de posse desses dados e análises, é possível se formular hipóteses para se testar quanto à política confrontacional ou disruptiva no contexto histórico que se abre com o Novo Regime Fiscal.

Há, portanto, no que concerne à relação entre o Novo Regime Fiscal e a participação política (convencional ou confrontacional), um amplo campo científico-político a se explorar, digno de produzir análises e interpretações que sugiram, quando menos, pertinentes perguntas e hipóteses não apenas para a compreensão da cena política doméstica, mas para a produção de pesquisas análogas em outros países.

\section{CONCLUSÕES}

A pesquisa teórica que informa este artigo propôs-se a cumprir os seguintes propósitos: i) resgatar a relevância do elemento fiscal substantivo para o campo da teoria do Estado e da própria teoria demo- 
crática, esta última prevalecentemente atada, no Brasil, a debates procedimentais; ii) sintetizar os argumentos teóricos que sugerem um desgaste da democracia no Norte Global, em razão do primado dos mercados em detrimento dos povos; e iii) propor, enfim, uma agenda de pesquisas que, por ensejo da promulgação da Emenda Constitucional 95/2016, investigue o diagnóstico de "pós-democracia" ou "era da austeridade" para o específico caso das relações políticas do Brasil contemporâneo.

O debate sobre o Estado e a democracia contemplou, até a segunda metade do século XX, ao menos no campo crítico, uma preocupação com elementos substantivos, em especial quanto à esfera da economia política e das tensões entre as desigualdades de classe inscritas no modo de produção capitalista e a igualdade de participação - quando menos, eleitoral - necessária até mesmo às minimalistas concepções de democracia (Miguel, 2012). Atualmente, todavia, a abordagem empírica e teórica do campo acadêmico da Ciência Política prioriza as questões de procedimento, com ênfase nas regras do jogo eleitoral, no sistema partidário e no funcionamento das instituições legislativas e executivas. Impera, assim, "uma redução do alcance social da democracia para uma visão formalista" (Marques e Machado, 2015:8). O que o resgate bibliográfico apresentado na segunda seção deste artigo procurou indicar é que, mesmo em leituras claramente procedimentais sobre a democracia - como as de Schumpeter e Downs - há um solo substantivo, a ancorar os procedimentos democráticos sobre uma base tributária e orçamentária indecomponível do Estado e de toda a sua atuação.

A partir do entendimento de que a fiscalidade importa para a política democrática, apresentou-se uma gama de produções contemporâneas segundo as quais, na Europa e nos EUA da atualidade, sob o primado dos credores da dívida pública e diante das sucessivas políticas identificadas com o conceito de austeridade fiscal, os padrões de participação política e de relação entre sociedade, Estado e mercado parecem sugerir que a democracia, inobstante o modo como se defina tão polissêmica noção, encontra-se sob risco, afetada por um cenário em que o governo se converte em governança e o povo - inobstante a definição que se confira à ideia - cede terreno em favor daquilo que Wolfgang Streeck define como marktsvolk, ou a base social legitimadora das decisões públicas referenciada em parâmetros estritamente associados à lógica econômica, antes de política (Brown, 2015; Streeck, 2016). 
O desafio que se apresenta à Ciência Política brasileira reside em efetivar um necessário "retorno" à economia política ${ }^{28}$. O Brasil experimenta, a partir da promulgação da Emenda Constitucional 95/2016, a mais profunda medida de austeridade - sob os critérios do rol de gastos congelados, do prazo de duração, das sanções institucionais e do instrumento normativo adotado - já conhecida. Assim, trata-se de um caso extremo em relação ao qual incontáveis perguntas de pesquisas em Ciência Política podem ser respondidas, como indicam as nada exaustivas sugestões arroladas na quarta seção. $\mathrm{O}$ "ataque à fortaleza da sociologia política" (Limongi et. al. 2015:4) que reorientou o campo acadêmico para temas como "poderes individualmente; federalismo, relações intergovernamentais e políticas públicas; regimes políticos e transição de regime" (ibid.:27) talvez tenha encontrado tempo de uma trégua com seu antigo opositor. $\mathrm{O}$ fato é que, mantendo-se o desenho formal das instituições brasileiras quanto a elementos como divisão de poderes, processo eleitoral e federalismo, o Novo Regime Fiscal trouxe à realidade do país uma definição $a$ priori das prioridades orçamentárias por um período de 20 anos. Essa transformação, de ordem não diretamente procedimental ou associada ao desenho institucional da máquina estatal, encerra um potencial para irradiar consequências sobre a dinâmica da democracia e da participação política no país.

A pesquisa empírica e teórica dedicada aos impactos do Novo Regime Fiscal sobre esferas como comportamento eleitoral, desigualdades, formulação e implementação de políticas públicas e relação entre Estado e mercado, dentre inúmeras outras, faz-se, portanto, indispensável para que o campo acadêmico da Ciência Política harmonize os seus objetos de estudo com as novidades e complexidades do atual contexto sócio-histórico.

(Recebido para publicação em 24 de outubro de 2017)

(Reapresentado em 29 de dezembro de 2018)

(Reapresentado em 14 de março de 2019)

(Aprovado para publicação em 2 de abril de 2019)

\section{NOTAS}

1. Transcorridos dez anos da vigência da medida, será possível revê-la, desde que por meio da rígida figura da Lei Complementar.

2. A medida contemplou as finanças da União, mas imposição da mesma ordem, acrescida de inúmeras determinações restritivas adicionais, são previstas na Lei Complementar 159/2017, que estabelece condições para a negociação das dívidas estaduais administradas pela Secretaria do Tesouro Nacional (Brasil, 2017). 
3. A norma estabeleceu um rol limitado de exceções ao teto de gastos, a contemplar, por exemplo, despesas eleitorais e aumento do capital de empresas estatais não dependentes.

4. As sanções institucionais foram introduzidas no Brasil com o advento da Lei de Responsabilidade Fiscal e remanescem como um tema lacunoso nos ensaios, interpretações e trabalhos empíricos das ciências sociais. No campo jurídico, há publicações que questionam a constitucionalidade do expediente (Derzi, 2002), em razão de afetar-se aos cidadãos os ônus do descumprimento de uma norma por parte dos respectivos governantes.

5. Um exemplo foi a aprovação da Lei 13.467/2017, que suprimiu direitos trabalhistas e, dentre outras disposições, inseriu o art. 611 na Consolidação das Leis do Trabalho (CLT) para dispor sobre a prevalência de acordos ou convenções coletivas em prejuízo dos direitos legislados em 15 hipóteses, oscilantes desde temas como jornada de trabalho, até o enquadramento de serviços insalubres.

6. Uma vez aprovado o Novo Regime Fiscal, o Governo Federal encaminhou ao Congresso Nacional a Proposta de Emenda Constitucional de número 287, cujo teor visa a alterar as regras da previdência social e da assistência social no Brasil, com imposição de requisitos mais rígidos para acesso aos direitos e potencial impacto sobre o aprofundamento das desigualdades de classe, gênero e região. Quanto aos possíveis impactos da medida sobre a população rural brasileira, confira-se Arrais (2017). Sobre os problemas metodológicos e empíricos dos estudos que respaldam a proposta, confira-se Puty e Gentil (2017).

7. Tradução livre. No original: [austerity is] "a form of voluntary deflation in which the economy adjust through the reduction of wages, price, and public spending to restore competitiveness, which is (supposedly) best achieved by cutting the state's budget, debts, and deficits".

8. A partir de 2015, a principal associação empresarial do Brasil, a Federação das Indústrias do Estado de São Paulo (Fiesp), somou-se aos protestos em favor da deposição da presidente Dilma Roussef com uma adicional pauta referente à redução dos tributos, sob o lema "Eu não vou pagar o pato".

9. Dois emblemáticos exemplos dessas exonerações encontram-se na Lei 9.429/95, cujo artigo 9o dispõe sobre a exclusão da base de cálculo do Imposto de Renda das Pessoas Jurídicas dos valores pagos a título de juros sobre o capital próprio aos respectivos acionistas, sócios ou titulares e cujo art. $10^{\circ}$ estabelece uma norma de isenção, para as pessoas físicas, dos acréscimos patrimoniais percebidos a título de dividendos ou lucros (Brasil, 1995).

10. Confira-se: “Os ingredientes que compõem o quadro sociopolítico brasileiro atual são vários: polarização social e ideológica, mobilização popular e estudantil, crise política, crise fiscal, quadro econômico de recessão aguda e desemprego massivo, disputa e reconfiguração eleitoral, uma mídia oligopolizada cada vez mais partidarizada e alinhada a setores específicos da estrutura de poder, crescente fascismo nos elementos de nossa cultura política, já historicamente iliberal, anomia institucional judiciária e estratagemas partidários se articulam formando cenário inimaginável até alguns anos atrás" (Santos e Szwako, 2017:115)

11. A pesquisa científico-política concentrada sobre temas como austeridade, tributação e orçamentação insere-se em um movimento de retorno à sociologia política e à economia política experimentado globalmente pelo campo a partir de eclosão da crise econômica de 2008. Sobre esse contexto, confira-se o seguinte excerto: "The crisis of Western-liberal democracy has apparently grown to a point where it can no longer be ignored by mainstream 
political science [...] it is begining to make its leading representatives to leave behind institutionalism pure and simple and move forward (or in fact back) to a political economy perspective on democracy that deserves its name" (Streeck, 2016:185). Há, por outro lado, uma influente gama de pesquisadores da Ciência Política que, a par de reconhecer a crise dos regimes democráticos contemporâneos ao não implementarem as medidas pretendidas pelos cidadãos, recorrem a explicações institucionais para as dificuldades ocorrentes na atualidade e apontam, normativamente, para saídas como aumento da ação coercitiva e repressiva do Estado (cf. Fukuyama, 2015).

12. A política de austeridade atualmente prevalecente em âmbito global encontra suas origens no preciso momento em que os elementos do Estado Social (como previdência e saúde pública universais) reverteram-se ou deixaram de expandir-se, o que já pode ser notado desde a década de 1980 (Pierson, 2001). Após a crise de 2008, em especial a partir de 2011, há uma exacerbação e ampliação desta tendência, com mais nítida vinculação do Estado à lógica e aos parâmetros do mercado, de modo a emergir uma autêntica "era da austeridade" (Schäffer e Streeck, 2013).

13. É certo que, ainda antes do século XX, temas fiscais ganharam destaque na teoria social. Veja-se, por exemplo, como, no século XIX, Marx e Engels apresentavam a progressividade tributária como uma importante reivindicação no Manifesto Comunista (Marx e Engels, 2005). O mesmo sucede no clássico O 18 Brumário de Luís Bonaparte, em que Marx já associa legitimidade política a tributos, ao descrever a relação entre os impostos sobre o vinho e a busca por apoio governamental junto à classe média (Marx, 2011). Há uma vertente minoritária dos estudos fiscais que vai além e defende que a tributação é tema socialmente relevante e intelectualmente discutido desde a Babilônia (Murphy, 2015).

14. A sofisticação filosófica que inspirou Marx a dialogar com a noção hegeliana de Estado (Marx, 2005), de maneira a ver na cidadania liberal um vazio "gênero sem corpo" é adotada - em tons mais simples e menos herméticos - por Goldscheid, para quem a democratização e a horizontalização da cidadania são concomitantes à perda da autonomia econômica do poder político. Para Goldscheid, "[T]he masses which eventually acquired greater power in the State saw themselves cheated of their prize when they got not the rich State but the poor one" (Goldscheid, 1994:205).

15. Tradução livre. No original: "the spirit of a people, its cultural level, its social structure, the deeds its policy may prepare - all this and more is written in its fiscal history, stripped of all phrases".

16. A formulação apresentada por J. Schumpeter para o conceito científico de democracia possui um caráter fundamental - seja pelo volume de aplicações, de adaptações ou de críticas que impulsiona - na teoria democrática contemporânea (Shapiro, 2002).

17. Sobre a decadência de uma ciência unificadamente dedicada ao estudo da economia, da política, da administração pública e do direito - Staatswissenchaft - em lugar de campos disciplinares especializados, confira-se Backhaus (2001).

18. Tradução livre. No original: "each national election can be considered a contest between two prospective goverrnment budgets".

19. Para Streeck esse é, precisamente, o caso: "almost a century after Schumpeter's seminal paper on the tax state, we are looking back at the rise and fall of what had turned into 
a debt state in the 1980s, give way two decades later to what today is shaping up as a consolidation state" (Streeck, 2013:16).

20. Sobre os limites estruturais da arrecadação fiscal no Estado capitalista e sua incompatibilidade com a democracia, o marxista James O'Connor fora ainda mais incisivo e propusera que não é apenas a relação de trabalho assalariado que implica extração de mais-valor ou exploração da classe trabalhadora. O Estado, em suas práticas de arrecadação fiscal, também é um agente de dominação e de exploração orientada por fatores de classe. O autor estabelece uma distinção entre os gastos orçamentários que potencializam o capital monopolista, em geral destinados a trabalhadores de grandes empresas; e os gastos referentes à "crise de legitimação" (expressão igualmente adotada por $\mathrm{O}^{\prime}$ Connor), atinentes à mão de obra excedente e relacionada a movimentos como os de negros, mulheres e minorias (O'Connor, 2009).

21. A polissêmica noção de democracia não exige, neste artigo, uma definição unívoca. Ao contrário, o que se discute é, precisamente, o solo fiscal comum às múltiplas variantes da teoria democrática contemporânea, bem como a incidência de uma tensão entre democracia e austeridade manifestada em diferentes apreensões da ideia de regime democrático. Estratégia similar, adotada para estudar as implicações filosóficas da relação entre neoliberalismo e democracia, fora adotada por Wendy Brown (2015).

22. Uma importante exceção, a ser mencionada na seção subsequente, encontra-se em Kaplan (2013).

23. O próprio epistemólogo assim explica a preferência por casos extremos em detrimento dos "típicos": "typical or average case is often not the richest in information. Atypical or extreme cases often reveal more information because they activate more actors and more basic mechanisms in the situation studied" (Flyvjberg, 2006:13).

24. Às particularidades abordadas, soma-se apenas mais uma terceira, adiante definida como "austeridade jurídica inata", que conformará, por si só, o eixo de um problema científico a informar a agenda de pesquisas adiante sugerida.

25. Vejam-se dois exemplos: a precariedade do processo transicional pode ser atribuída à Espanha e as pronunciadas desigualdades econômicas podem ser notadas em Estados como Nova Orleans, nos EUA.

26. Tradução livre; no original: "In none of the three countries are the ceilings regulated in legislation, and there are no predetermined sanctions for exceeding the ceiling".

27. Uma interpretação rival, que infirma o absenteísmo eleitoral no Brasil em 2016, foi apresentada por Limongi (2016).

28. Uma abordagem sociológico-política sobre as decisões econômicas proferidas no Brasil, cujas perspectivas podem servir de referência para as pesquisas que virão por ocasião do Novo Regime Fiscal, encontra-se no trabalho de Daniel Bin, dedicado aos processos decisórios referentes às políticas fiscal e monetária (Bin, 2015). Já no plano interdisciplinar entre a economia política e o estudo das políticas públicas, a pesquisa sobre as políticas de benefícios tributários conduzida por Wagner Mancuso e Davi Moreira figura como exemplo de abordagens cuja proliferação seria benfazeja à Ciência Política brasileira (Mancusco e Moreira, 2013). 


\section{REFERÊNCIAS}

ALESINA, Alberto; FAVERO, Carlo; GIAVAZZI, Franceso. (2015), “The output effect of fiscal consolidation plans". Journal of International Economics, v. 96, sup. 1, pp. 19-42.

ARRAIS, Tadeu Alencar. (2017), Risco social no campo: a reforma previdenciária e o fim da aposentadoria rural. Goiânia: Editora UFG.

AVRITZER, Leonardo (org.). (2009), Experiências nacionais de participação social. São Paulo: Cortez.

. (2010), A dinâmica da Pparticipação Llocal no Brasil. São Paulo,; Cortez.

BACKHAUS, Jürgen G. (2002), "Fiscal Sociology: What for?”. In: J. Backhaus; R. Wagner (eds.), Handbook of Public Finance. London: Springer, pp. 521-541.

BARKER, Colin et al. (2013), "Marxism and social movements: an introduction”. In: C. Barker et al. (eds.), Marxism and social movements. Leiden: Brill, pp. 1-40.

BIN, Daniel. (2015), "Macroeconomic policies and economic democracy in neoliberal Brazil". Economia e Sociedade, v. 24, n. 33, pp. 513-539.

BLYTH, Mark. (2013), Austerity: the history of a dangerous ideia. Oxford: Oxford University Press.

BRASIL. (1995), Lei 9.429, de 26 de dezembro de 1995. Altera a legislação do imposto de renda das pessoas jurídicas, bem como da contribuição social sobre o lucro líquido, e dá outras providências. Disponível em: http:/ / www.planalto.gov.br/ccivil_03/LEIS/L9249.htm. Acesso em 29 de dezembro de 2018.

. (2016), Emenda Constitucional 95, de 15 de dezembro de 2016. Altera o Ato das disposições Constitucionais Transitórias, para instituir o Novo Regime Fiscal, e dá outras providências. Disponível em: http://www.planalto.gov.br/ccivil_03/constituicao/emendas/emc/ emc95.htm. Acesso em 28 de dezembro de 2018.

. (2017), Lei Complementar 159, de 19 de maio de 2017. Institui o regime de recuperação fiscal dos Estados e do Distrito Federal e altera as Leis Complementares número 101, de 4 de maio de 2000 e número 156, de 28 de dezembro de 2016. Disponível em: http:/ / www.planalto.gov. br/ccivil_03/leis/LCP/Lcp159.htm. Acesso em 28 de dezembro de 2018.

BRINGEL, Breno; PLEYERS, Geoffrey. (2015), “Les mobilisations de 2013 au Brésil: vers une reconfiguration de la contestation”. Bresil(s), v. 7, pp. 7-18.

BROWN, Wendy. (2015), Undoing the Demos: Neoliberalism's Stealth Revolution. New York: Zone Books.

CODATO, Adriano. (2018), “Comparando a Ciência Política Brasileira com a Estrangeira. Apresentação disponibilizada em repositório pessoal do autor". Disponível em: https:/ / www.academia.edu/37983747/Comparando_a_Ci\%C3\%AAncia_Pol\%C3\%ADtica_brasileira_com_a_estrangeira. Acesso em 15 de dezembro de 2018.

CROUCH, Colin. (2004), Post Democracy. Cambridge: Polity.

DAGNINO, Evelina. (2014), “Construção democrática, neoliberalismo e participação: os dilemas da confluência perversa". Política e Sociedade, n. 5, pp. 139-164. 
Francisco Tavares e Gustavo Silva

DELLA PORTA, Donatella. (2015), Social movements in times of austerity. Cambridge: Polity.

DERZI, Misabel. (2002), "Da inconstitucionalidade das sanções institucionais impostas pela Lei de Responsabilidade Fiscal". In: C. V. Nascimento (coord.), Lei de Responsabilidade Fiscal: Teoria e Prática. Rio de Janeiro: América Jurídica, pp. 189-238.

DRIESSEN, Grant A.; LABONTE, Marc. (2015), "The Budget Control Act of 2011 as Amended: Budgetary Effects". CRS Report, no 42.506. Disponível em: https:/ / fas.org/sgp/ crs/misc/R42506.pdf. Acesso em 11 de março de 2019.

DOWNS, Anthony. (1999), Uma teoria econômica da democracia. Trad.: de Sandra Guardini Teixeira Vasconselos. São Paulo: Edusp.

. (1960), "Why the government budget is too small in a democracy?". World Politics, v. 12, n. 4 , pp. 541-563.

ELIAS, Norbert. (2011), O processo civilizador. Volume 2: formação do Estado e Civilização. Trad.: de Ruy Jungmann. Rio de Janeiro: Zahar.

FLYVBERG, B. (2001), Making social science matter: why social inquiry failed and how it can suceed again. Cambridge: Cambridge University Press.

FMI (Fundo Monetário Internacional). (2017), "IMF fiscal monitor: tackling inequality". Disponível em: https: / /www.imf.org/en/Publications/FM/Issues/2017/10/05/fiscal-monitor-october-2017. Acesso em 9 de dezembro de 2017.

FOMINAYA, Cristina Flesher. (2014), Social movements and globalization: how protests, occupations and uprisings are changing the world. Basingstoke: Palgrave Macmillan.

FUKUYAMA, Francis. (2015), “Why is democracy performing so poorly?". Journal of Democracy [online]. v. 26, n. 1. Disponível em: https:/ / fsi.stanford.edu/sites/default/files/ ff_jod_jan2015.pdf. Acesso em 10 de julho de 2017.

GOBETTI, Sérgio W.; ORAIR, Rodrigo O. (2016), “Progressividade Tributária: a agenda negligenciada". Ipea -Texto Para Discussão [online]. n. 2190. Disponível em: http:/ / repositorio. ipea.gov.br/bitstream/11058/6633/1/td_2190.pdf. Acesso em 11 de março de 2019.

GOLDSCHEID, R. (1994), "A sociological approach to problems of public finance". In: R. Musgrave; A. T. Peacock (eds.), In: Classics in the theory of public finance. London: MacMillan, pp. 202-213.

GUAJARDO, Jaime; LEIGH, Daniel; PESCATORI, Andrea. (2011), “Expansionary austerity: new international evidence". International Monetary Fund Working Paper [online]. $\mathrm{n}^{\circ}$ 11/58. Disponível em: https: / /www.imf.org/external/pubs/ft/wp/2011/wp11158. pdf. Acesso em 10 de março de 2019.

HABERMAS, Jürgen. (2002), A crise de legitimação no capitalismo tardio. Trad.: Vamireh Chacon. Rio de Janeiro: Tempo Brasileiro.

HAFFERT, Lukas; MEHRTENS, Philip. (2013), "From austerity to expansion? Consolidation, budgets surpluses, and the decline of fiscal capacity". MPIFG Discussion Paper [online]. v. 13, n. 16. Disponível em: https://www.mpifg.de/pu/mpifg_dp/dp13-16.pdf. Acesso em 12 de dezembro de 2018.

HOLMES, Stephen; SUNSTEIN, Cass. (1999), The cost of rights: why liberty depends on taxes. London: Norton.

DADOS, Rio de Janeiro, vol.63(2): e20180320, 2020. 
KAPLAN, Stephen. (2013), Globalization and austerity politics in Latin America. Cambridge: CUP.

LIMONGI, Fernando. (2016), “Analistas superestimam absenteísmo eleitoral em 2012". Folha de São Paulo Online [online]. Disponível em: http:/ / www1.folha.uol.com.br/ ilustrissima/2016/11/1831315-analistas-superestimam-absenteismo-eleitoral-em-2016. shtml.

LIMONGI, Fernando; ALMEIDA, Maria Hermínia Tavares de; FREITAS, Andrea. (2015), “Da Sociologia Política ao (neo) institucionalismo: trinta anos que mudaram a Ciência Política no Brasil". In: L. Avritzer; C. Milani (orgs.), Repositório pessoal da autora Maria Hermínia Tavares de Freitas [online]. Disponível em: https:/ / www.academia.edu/15209689/DA_SOCIOLOGIA_POL\%C3\%8DTICA_AO_NEO_INSTITUCIONALISMO_TRINTA_ANOS_ QUE_MUDARAM_A_CI\%C3\%8ANCIA_POL\%C3\%8DTICA_NO_BRASIL. Acesso em 11 de março de 2019.

LJUNGMAN, Gösta. (2008), "Expenditure celings: a survey". IMF Working Paper [online], no 282. Disponível em: https:/ / papers.ssrn.com/sol3/papers.cfm?abstract_id=1316750. Acesso em 11 de março de 2019.

MACHADO, Carlos; MARQUES, Danusa; CAMPOS, Luiz Augusto. (2017), “De onde veio essa abstenção toda?". Blog do Demodê [online]. Disponível em: https:/ / grupo-demode. tumblr.com/post/151300334522/de-onde-veio-essa-absten\%C3\%A7\%C3\%A3o-toda. Acesso em 11 de março de 2019.

MANCUSO, Wagner Pralon; MOREIRA, Davi Cordeiro. (2013), "Benefícios tributários valem a pena? - um estudo de formulação de políticas públicas". Rev. Sociol. Polit. [online], v. 21, n. 45, pp.107-121. Disponível em: http://dx.doi.org/10.1590/S0104-44782013000100009. Acesso em 11 de março de 2019.

MARQUES, Danusa; MACHADO, Carlos. (2015), "Apresentação". In: L. F. Miguel et al. (orgs.), A democracia face às desigualdades: problemas e horizontes. São Paulo: Alameda.

MARTIN, Isaac; MEHROTRA, Ajay; PRASAD, Monica. (2009), “The Thunder of History: the origins and development of the new fiscal sociology." In: I. Martin; A. Mehrotra; M. Prasad (eds.), The new fiscal sociology: taxation in comparative and historical perspective. Cambridge: Cambridge University Press, pp. 1-28.

MARX, Karl. (2005), A crítica da Filosofia do Direito de Hegel. Trad.: de Rubens Enderle eE Leonardo de Deus. São Paulo: Boitempo.

MARX, Karl. (2011), O 18 Brumário de Luís Bonaparte. Trad.: Nélio Schneider. São Paulo: Boitempo.

MARX, Karl; ENGELS, Friedrich. (2005), Manifesto Comunista. Trad.: Álvaro Pina. São Paulo: Boitempo.

MEIRELLES, Henrique de Campos; OLIVEIRA, Dyogo Henrique de. (2016), Exposição de Motivos 00083/2016. Disponível em: http:/ /www.planalto.gov.br/ccivil_03/projetos / expmotiv/emi/2016/83.htm. Acesso em 11 de março de 2019.

MIGUEL, Luis Felipe. (2012), "Democracia e sociedade de classes". Revista Brasileira de Ciência Política, n. 9, pp. 93-117. 
MORLINO, Leonardo; QUARANTA, Mario. (2016), "What is the impact of the economic crisis on democracy? Evidence from Europe". International Political Science Review [online], v. 37, n. 5. Disponível em: https://journals.sagepub.com/doi/10.1177/0192512116639747. Acesso em 11 de março de 2019.

MURPHY, Richard. (2015), The joy of tax. London: Transworld Publishers.

NEVES, Marcelo. (1996), “Constitucionalização simbólica e desconstitucionalização fática: mudança simbólica da Constituição e permanência das estruturas reais de poder". Revista de Informação Legislativa, n. 132, pp. 321-330.

NORDHAUS, Willian D. (1975), "The political business cycle". Review of Economic Studies, v. 42, n. 2 , pp. $169-190$.

O'CONNOR, James. (2008), The fiscal crisis of the State. New Brunswick: Transaction Publishers.

OFFE, Claus. (2013), "Participatory inequality in the austerity state: a supply-side approach". In: A. Schäfer; W. Streeck (eds.), Politics in the age of austerity. Cambridge: Polity, pp. 196-218.

PIERSON, Paul. (2001), "From expansion to austerity: the new politics of taxing and spending”. In: M. A. Levin; M. K. Landy; M. Shapiro (eds.), Seeking the center: politics and policymaking in the new century. Washington: Georgetown University Press, pp. 54-80.

PINTO, Élida Graziane. (2014), “Eficácia dos direitos sociais por meio do controle judicial da legalidade orçamentária e da sua adequada execução.". Revista Fórum de Direito Financeiro e Econômico, v. 3, n. 5, pp. 71-100.

PUTY, Cláudio Alberto Castelo Branco; GENTIL, Denise Lobato (orgs.). (2017), A Previdência Social em 2060: as inconsistências do modelo de projeção atuarial do governo brasileiro. Brasília: ANFIP/DIEESE.

ROSA, Everto Sotto Tibiriçá. (2016), A Eeconomia mMonetária de Keynes: aA moeda e o sistema financeiro a serviço da produção ou a administração financeira estatal. Tese (Doutorado em Economia)., Universidade de Campinas:, Campinas.

SAFATLE, Vladimir. (2017), Só mais um esforço. São Paulo: Três Estrelas.

SANTOS, Boaventura de Sousa e AVRITZER, Leonardo. (2002), “Introdução: para ampliar o cânone democrático". In: B. de S. Santos (org.), Democratizar a democracia: os caminhos da democracia participativa. Rio de Janeiro: Civilização Brasileira, pp. 39-82.

SANTOS, Fabiano e SZWAKO, José. (2016), “Da ruptura à reconstrução democrática no Brasil". Saúde Debate, v. 40, pp. 114-121.

SCHÄFER, A e STREECK, W. (2013), “Introduction”. In: A. Schäfer; W. Streeck (eds.), Politics in the Age of Austerity. Cambridge: Polity, pp. 1-25.

SCHUMPETER, Joseph A. (1961), Capitalismo Socialismo, e Democracia. Trad.: de Ruy Jungmann. São Paulo: Fundo de Cultura.

. (1991), "The crisis of the tax state". In: R. Swedberg (ed.), Joseph A. Schumpeter: the economics and ssociology of ccapitalism. Princeton: Princeton University PressPUP, pp. 99-140.

SINGER, André. (2012), Os sentidos do lulismo: reforma gradual e pacto conservador. São Paulo: Companhia das Letras.

DADOS, Rio de Janeiro, vol.63(2): e20180320, 2020. 
SHAPIRO, Ian. (2002), "The state of democratic theory". In: I. Katznelson; H. V. Melner (eds.), Political Science: state of the discipline. New York: Norton.

STEUERLE, Eugene. (2019), "Restoring fiscal democracy". The Milken Institute Review [online]. 2016, 1st quarter. Disponível em: https:/ / www.urban.org/sites/default/files/ publication/80326/2000781-Restoring-Fiscal-Democracy.pdf. Acesso em 11 de março de 2019.

STREECK, Wolfgang; MERTENS, Daniel. (2010), "An index of fiscal democracy". MPIfG Working Paper [online], n. 10. Disponível em: https://www.mpifg.de/pu/workpap/ wp10-3.pdf. Acesso em 11 de março de 2019.

STREECK, Wolfgang. (2013), “The politics of public debt: neoliberalism, capiltalist development and the restructuring of the State". MPIfG Working Paper [online], n. 13. Disponível em: https:/ / www.mpifg.de/pu/mpifg_dp/dp13-7.pdf. Acesso em 11 de março de 2019.

. (2014), Buying time: the delayed crisis of democratic capitalism. London: Verso.

. (2016), How will capitalism end?. London: Verso.

. (2011), "The crises of democratic capitalism". New Left Review, n. 71, pp. 5-29.

TILLY, Charles. (2007), Democracy. Cambridge: CUP.

YOUNG, Iris Marion. (2001), "Activist challenges to deliberative democracy". Political Theory, v. 29, n. 5 , pp. $670-690$. 


\section{RESUMO \\ A Ciência Politica Brasileira Diante do Novo Regime Fiscal: Para uma Agenda de Pesquisas sobre Democracia e Austeridade}

Este artigo pretende identificar alguns problemas e temas de pesquisa que se descortinam para a Ciência Política brasileira sob o cenário social, político e econômico aberto com a promulgação do Novo Regime Fiscal no país. A partir de uma pesquisa teórica que revisita referências oriundas de matrizes tão distintas como a public choice e o deliberacionismo, identifica-se a centralidade da dimensão fiscal para a formação e o funcionamento dos regimes democráticos. Desta premissa, constata-se uma homologia entre regimes fiscais e regimes políticos, decorrente da propriedade que aqueles têm de influenciarem as instituições, as políticas públicas e os interesses políticos ocorrentes nestes. Percebe-se, adicionalmente, que as alterações constitucionais experimentadas na lógica das finanças públicas brasileiras podem ser classificadas como um caso extremo de fiscalidade impulsionada pelo horizonte normativo associado à ideia de austeridade expansionista. Assim, propugna-se que as pesquisas teóricas e empíricas, atualmente mais frequentes no Norte Global, sobre a tensa relação entre constrição orçamentária e política democrática, encontram no Brasil um ambiente especialmente propício para serem conduzidas.

Palavras-chaves: austeridade; novo regime fiscal; Ciência Política brasileira; teoria democrática; economia política

\section{ABSTRACT \\ Brazilian Political Science in the New Fiscal Regime: Towards a Research Agenda on Democracy and Austerity}

This article aims to identify some problems and research themes that unfold for Brazilian Political Science under the social, political and economic scenario created with the promulgation of the New Fiscal Regime in the country. Through a theoretical research that revisits references from such different matrices as public choice and deliberationism, the centrality of the fiscal dimension to the formation and functioning of democratic regimes is identified. From this premise, we see a homology between tax regimes and political regimes, due to the property that the former have to influence the institutions, public policies, and political interests that occur in the latter. Moreover, the constitutional changes experienced in the logic of Brazilian public finances can be classified as an extreme case of taxation driven by the normative horizon associated with the idea of expansionist austerity. Thus, it 
is argued that theoretical and empirical research, nowadays particularly common in the Global North, on the tense relationship between budget constraint and democratic politics, find in Brazil an especially conducive environment to conduct.

Keywords: austerity; new fiscal regime; brazilian Political Science; democratic theory; political economy

\section{RÉSUMÉ}

La Science Politique Brésilienne Dans le Nouveau Régime Fiscal: Vers un Programme de Recherche sur la Démocratie et L'austérité

Cet article vise à identifier certains problèmes et thèmes de recherche qui se déroulent pour la Science Politique brésilienne dans le cadre du scénario social, politique et économique ouvert avec la promulgation du nouveau régime fiscal dans le pays. À partir d'une recherche théorique qui revisite les références de matrices aussi différentes que le choix public et le "délibérationnisme", la centralité de la dimension fiscale est identifiée pour la formation et le fonctionnement des régimes démocratiques. De cette prémisse, il existe une homologie entre les régimes fiscaux et les régimes politiques, en raison de leur propriété d'influencer les institutions, les politiques publiques et les intérêts politiques qui s'y produisent. De plus, les changements constitutionnels rencontrés dans la logique des finances publiques brésiliennes peuvent être classées comme un cas extrême de taxation entraîneé par l'horizon normatif associé à l'idée d'austérité expansionniste. Ainsi, il est avancé que les recherches théoriques et empiriques actuellement les plus fréquentes dans le Nord global sur la relation tendue entre la contrainte budgétaire et la politique démocratique trouvent au Brésil un environnement particulièrement propice à la conduite.

Mots-clés: austérité; nouveau régime fiscal; Science Politique brésilienne; théorie démocratique; économie politique

\section{RESUMEN}

La Ciencia Política Brasilera Frente al Nuevo Régimen Fiscal: Hacia una Agenda de Investigaciones sobre Democracia y Austeridad

Este artículo pretende identificar algunos problemas y temas de investigación que se divisan para la Ciencia Política brasilera sobre el escenario social, político y económico abierto con la promulgación del Nuevo Régimen Fiscal en el país. A partir de una investigación teórica que revisa referencias oriundas de matrices tan distintas como el public choice y el deliberacionismo, se identifica la centralidad 
de la dimensión fiscal para la formación y el funcionamiento de los regímenes democráticos. De esta premisa, se constata una homología entre regímenes fiscales y regímenes políticos, derivado de la propiedad que los primeros tienen de influenciar las instituciones, las políticas públicas y los intereses políticos. Se percibe, adicionalmente, que las alteraciones constitucionales experimentadas en la lógica de las finanzas públicas brasileras pueden ser clasificadas como un caso extremo de fiscalidad impulsada por el horizonte normativo asociado a la idea de austeridad expansionista. Así, se propugna que las investigaciones teóricas y empíricas, actualmente más frecuentes en el Norte Global, sobre la tensa relación entre restricción presupuestaria y política democrática, encuentran en Brasil un ambiente especialmente propicio para que sean conducidas.

Palabras clave: austeridad; nuevo régimen fiscal; Ciencia Política brasilera; teoría democrática; economía política 